\title{
A ROBOTOKKAL TÖRTÉNŐ OKTATÁS AZ ÉLMÉNYPEDAGÓGIA ASPEKTUSÁBÓL
}

\section{Szerzők:}

Mező Katalin (PhD)

Debrecen Egyetem

Szabóné Burik Erika

Éltes Mátyás Általános Iskola

Első szerző e-mail címe:

kata.mezo1@gmail.com
Lektorok:

Molnár Balázs (PhD.)

Debrecen Egyetem

Szabóné Dr. Balogh Ágota (PhD)

Gál Ferenc Egyetem

és további két anonim lektor...

\begin{abstract}
Absztrakt
Háttér és cél: A tanulmány a robotokkal történő tanítás alkalmazásának lehetőségeiről szól. A tanulmány elméleti részében a robotok oktatási folyamatban való alkalmazásának főbb irányzatait elemezzük hazai és nemzetközi szinten. Ezt követi egy, a robotokkal történő oktatással kapcsolatos kutatás összefoglalása. Minta és módszer: A vizsgálatban 84 pedagógust kérdeztünk meg kérdőív használatával. Az eredményeket SPSS segítségével elemeztük leíró statisztikai analízissel és Chi-négyzet teszt számítás alkalmazásával.
\end{abstract}

Kulcsszavak: oktatás, robotika

Diszciplínák: pedagógia, informatika

\section{Abstract \\ USING ROBOTS IN THE TEACHING PROCESS \\ FROM AN EXPERIMENTAL EDUCATIONAL ASPECT}

Background and aim: The study is about the possibilities of using robots in the teaching process as an experimental educational method. In the theoretical part of the study, we analyze the main trends in using robots in the teaching process in Hungary and internationally. It is followed a summary of research about education with robots. Sample and method: In the study, we surveyed 84 teachers by filling out a questionnaire. The results were analyzed by SPSS, using descriptive statistical analysis and Chi-square test calculation.

Keywords: education, robotics

Disciplines: pedagogy, informatics 
Mező Katalin és Szabóné Burik Erika (2021): A robotokkal történő oktatás, az élménypedagógia aspektusából. Mesterséges intelligencia - interdiszciplináris folyóirat, III. évf. 2021/2. szám. 19-32. doi: 10.35406/MI.2021.2.19

Bár az élménypedagógia hazánkban is egyre gyakrabban felszínre kerülő irányzat (Kispéter és Sövényházy, 2008; Mező K., 2015), oktatásrobotikai szempontú megközelítésével még nem foglalkoztak. A téma vizsgálata ezért unikális és egyben meglehetôsen aktuális, mivel a digitális kultúra terjedésével egyre gyakrabban találkozunk ilyen típusú élménypedagógiai eszközzel az iskolákban, ugyanakkor az oktatásrobotikai eszközök hazai pedagógiai hatékonyságvizsgálatára csak ritkán került sor (lásd: Kiss, 2015). Az élménypedagógiára sokan úgy gondolnak, mint egyszerű, elsősorban outdoor (tantermen kívül) megvalósuló játékos tevékenység, holott ez az elképzelés hibás, hiszen az élménypedagógiának nem csak outdoor megvalósítási lehetőségei vannak, sôt fontos lenne, hogy a tantermen belül (indoor) is váljon élményszerūvé a felfedeztetésre, tapasztalatszerzésre épülő tanulás (Mező K., 2015; Mező F., 2021).

$\mathrm{Az}$ indoor élménypedagógia egyik megvalósulási formája lehet az oktatási célú robotika, mely a gamifikációs tartalmak mellett elősegíti a napjainkban egyre inkább hangoztatott - a jövőbeli életben való boldoguláshoz elengedhetetlen -, STEAM készségek (mozaikszó: a tudományos, a technológiai, a mérnöki, művészeti és a matematikai - Science, Technology,
Engineering, Art, Mathematics - területek nevének rövidítése) kialakítását (EU, 2015). E készségek iskolai fejlesztése elengedhetetlen, hiszen a mesterséges intelligencia, a robotika térhódításával, növekszik a munkaerőpiac azon igénye, hogy az iskolából kikerülő diákok rendelkezzenek azon csúcstechnológiás készségekkel, melyek alkalmassá teszik a tanulókat a magas minőségű, „high-tech” eszközök használatára. Tanulmányunkban az oktatásrobotika indoor élménypedagógiai felhasználásának lehetôségeivel foglalkozunk, vizsgálatunk elemzése által bepillantást nyerünk az oktatásrobotika helyzetébe a hazai általános iskolákban.

\section{A robotokkal történő oktatás, mint indoor élménypedagógia}

Az 1990-es évek végén megjelenő TIMMS és PISA nemzetközi oktatási kutatások rávilágítottak a tanuló korú gyermekek gyenge tanulmányi eredményeire (TIMMS, 1999; OECD, 2001). Ennek következményeként több figyelem irányult az új stratégiákra és megközelítésekre, az oktatási rendszer minőségének javítására (Kraetzschmar, 2009; Molnár, 2019). Az új megközelítések egyike a robotokkal történő oktatás volt, mely magával hozta annak a szükségességét is, hogy a korábban 
használt oktatási technológia tartalmát kibővítsék, és új teret nyissanak az oktatási célú robotika felé (Kärnä-Lin és tsai, 2006).

Az oktatási célú robotika olyan kézzelfogható, programozható eszközökkel, fizikai tárgyakkal, technológiákkal (mint például a programozható LEGO-val vagy ELEKIT-tel) történő pedagógiai fejlesztést jelent, amelyek felhasználhatók arra, hogy segítsék a megértést és a fogalomalkotást a tanulásban. A robotika olyan gépezetekkel foglalkozik, amelyek általában egy előre beprogramozott feladatsor megoldására képesek automatikus, vagy félautonóm módon, úgy hogy általában interakcióba lépnek a fizikai világgal. A manipulátorok, olyan mechanikus berendezések, melyek vagy emberi irányításúak, vagy ugyanazon beléjük táplált mozgás sorozatokat ismételve végzik el, így a robot talán legegyszerűbb megfogalmazása, az (újra)-programozható manipulátor (NAR, 2020). A robotokkal történő oktatás a kódolás vagy a programozás alapjait tanítja az osztálytermekben minden korosztály számára, lehetővé téve a modellek és funkciók konkretizálását aktív részvételi élménnyel. Így a modellek megvizsgálhatók, értékelhetők és fejleszthetők fogalmi és konkrét szinteken is.

Meg kell jegyeznünk, hogy a robotok pedagógiai célú felhasználása már korábban sem volt ismeretlen, hiszen Seymour Papert már az 1960-as években az elsők között alkalmazott robotokat az iskolai oktatás során: kifejlesztette a Logo programozási nyelvet és Teknőc nevü robotjait, s kísérleti jelleggel a hatékonyabb tanítás szolgálatába állította ezeket a tanulóknál. A technológia fejlődésével, az újabb kutatásoknak köszönhetően napjainkban is kitűnően alkalmazhatók a különféle robotok oktatási célokra (Aknai, 2020). Azonban a különböző országokban eltérő ritmusban és intenzitással jelentek meg a robotok az iskolákban. A következőkben az oktatásrobotika használatának élharcosai (Finnország és az USA), valamint hazánk oktatási robotikai elképzeléseibe nyújtunk betekintést.

\section{A robotokkal történő oktatás kezdetei Finnországban}

A finn oktatási rendszer az elsők között nyitott a robotika bevezetésére így mára már a hagyományos oktatás tanrendjének részét képezi, hogy az általános iskolás tanulók ne csupán megszerezzék az alaptudást a technológiáról, hanem képesek legyenek alkalmazni is azt. Ennek megfelelően kiemelkedő szerepet szánnak az élményalapú programozás és robotika tanításának (Taimela, 2020). Napjainkban az oktatásrobotika terén már ott tartanak, hogy Tampere egyik iskolájában kísérleti jelleggel (tanársegédként) négy beszélő robotot alkalmaznak, melyeket elsősorban a matematika és az idegen nyelvek tanításában használnak. A négy robot közül három az AI Robots alkotása, bagolyszerú kinézetű, míg a negyedik gépezet Elias, humanoid jellegű. E kísérlet célja annak megismerése, hogy a tanulók hogyan tudnak és akarnak együttműködni a beszélő robotokkal, valamint annak vizsgálata, 
hogy képesek-e a robotok javítani a tanítás minőségét és hatékonyságát (Net1).

Emellett érdekes kezdeményezés indult el a Joensuu Egyetem Számítástechnikai Tanszékén 2001-ben, mely középpontjában az edukációs robotika gyógypedagógiai funkciói, valamint a Technológia a Sajátos Nevelési Igényű Gyermekeknek Project eredményei állnak (Kärnä-Lin és tsai, 2006). Finnországban, ahol a tanulók $17 \%$-a sajátos nevelési igényű, rendkívül nagy szükség van az új gyógypedagógiai megoldások kifejlesztésére. A projekt elsődleges célja volt, hogy felfedezzen és kifejlesszen olyan technológiai megoldásokat, amiknek segítségével a sajátos igényű tanulók tanulási folyamata is támogatható. A projekt keretében összesen öt tanulócsoport dolgozott edukációs robotikával. Mindegyik tanuló tudott beszélni, de nehézségeik akadtak az írással, olvasással, és a feladatok önálló végzésével. A csoportlétszám 7 és 10 között mozgott (Kärnä-Lin és tsai, 2006). A program keretében a LEGO Mindstorms Robot Feltaláló Rendszer 2.0 és az ELEKIT építő szettek segítségével tárgyakat készítettek a tanulók. A LEGO RFR 2.0-val LEGO robotokat programoztak, a TileDesigner-t pedig ELEKIT robotokhoz használták. A tapasztalatok azt mutatták, hogy mind az öt csoportban emelkedett a csoportmunka készség és a tanulók egymás közötti interakciós szintje. Ez utóbbi olyan hajlandóságoknál volt megfigyelhető, mint javaslatok kérése vagy ötletek megosztása más tanulókkal, valamint többször fordult elő csoportos játék, mint egyéni. A tanárok azt is feljegyezték, hogy a szociális készségek használata a technológiai foglalkozás alatt eltért a többi óráétól. A nehéz fogalmak ismerőssé váltak, és a tanulók aktívan kezdték el őket használni a projekt alatt. Jellemző volt a tanulókra a motiváltság, lelkesedés és aktív részvétel a feladatok végzése közben (Kärnä-Lin és tsai, 2006). Az edukációs robotika és a programozás új lehetőségeket teremtettek a tanulók számára arra, hogy kifejezhessék önmagukat, továbbá magát a technológiát is megtanulták és egyéb készségeket is elsajátítottak. A programozás nagy kihívás volt a tanulók számára és több tanári segítségre volt szükség, ám a tanulók lelkesedése végig fenn maradt (Kärnä-Lin és tsai, 2006).

\section{A robotokkal történő oktatás kezde- tei az Amerikai Egyesült Államokban}

Az oktatási célú robotika bevezetésére már a '90-es évek végén sor került az USAban. Ekkor került sor a Tufts Egyetem mérnöki karán (a NASA támogatásával) a robotikával kísért tanítás bevezetésére a 330 éves korosztály számára. A program középpontjába a repüléstant állították, mely során a fó cél az volt, hogy bemutassanak a tanulóknak egy teljes mérnöki tervezési projektet (például egy repülőtér megépítését) miközben matematikát, természettudományt, olvasást és írást tanítanak. A feladat megvalósításához a LEGO robotikai elemeket választották technikai eszközkészletként a sokoldalúsága és a számítógépes felülete miatt (Net2). Később a 
Tufts Egyetem szövetséget alakított a National Instruments-szel és a LEGO-val, hogy kifejlesszék a szoftvert a LEGO elemek következő generációjához: az RCX-hez. Az RCX egy mikroprocesszorral ellátott LEGO elem. Ez lehetővé tette a tanulóknak, hogy elhagyják a számítógépet, és önálló robotegységekkel dolgozhassanak. Az RCX számos új kurzus része lett a főiskolán és az előkészítőn, ami felkeltette a diákok érdeklődését és hatékonyan tanította a műszaki fogalmakat soha nem látott tanulói részvétellel. A kutatás különlegessége az volt, hogy a főiskolás hallgatók és az óvodások ugyanazokat a hardver és szoftver eszközöket használták (természetesen a feladatok nehézségi foka különbözött - Net2). Emellett az elmúlt években kísérletezési technikákat is tanítottak, amely során használtak LEGO elemeket és a LabVIEW szoftvert.

A LEGO elemek bevonása bármelyik korosztályban szórakozást vitt a tanulásba, amely motiválta a tanulókat a tananyag megtanulásában. Az óvodától a főiskoláig a diákok számára nagyon érdekessé tette az építést, irányítást és versenyzést. A LabVIEW (ROBOLAB) és az RCX tanításba történő bevonásával a tanulók először megtanulják, hogy hogyan kell programozni, hogyan írjanak jelentéseket és hogyan elemezzék az adatokat, majd ezt követően felhasználják ezeket az ismereteket. A technika ezáltal kapcsolatot biztosít a tudomány és más tantárgyak között bármelyik évfolyamon. A LEGO elemek felhasználása izgalmas módja annak, hogy a tanulók kreatívak legyenek és saját magukénak érezzék, amit csinálnak. Arra is motiválják a tanulókat, hogy megtanulják a tananyagot (Net2).

\section{Robotokkal történő oktatás Magyarországon}

Hazánkban az oktatási célú robotika még gyerekcipőben jár, elterjedése az utóbbi 5 év vívmánya, mely nagyrészt a Digitális Oktatási Stratégia (a Kormány által 1536/2016. (X. 13.) Korm. határozattal elfogadott Magyarország Digitális Oktatási Stratégiája) eredményének tekinthető, amelynek hatására számos iskola jutott robotikai eszközökhöz. Azonban az oktatási célú robotika elterjedését számos tényező továbbra is gátolja (például az eszközök használatához szükséges tudás hiánya, az eszközök magas költsége, valamint a NAT kedvezőtlen óraszám eloszlása), melynek megoldása a közel jövő feladata.

Magyarországon a leginkább ismert oktatási célú robotok, az ú.n padlóbotok, ezek közül is a Bee-Bot, a Blue-Bot, az Ozobot, az Edison és az mBot.

A Bee-Bot, Blue-Bot robot méhecskék. „Mindkettő eszköz a méhecskéket modellezi, melyek a hátukon lévő iránygombok segítségével programozhatók. Könnyen a gyerekek kedvencévé válnak, hiszen amellett, hogy programozni lehet őket és végrehajtják a parancsokat, villognak és hangot is adnak. A méhecskék $15 \mathrm{x}$ 15 cm-es lépésekben tudnak közlekedni. Tökéletes eszköz a térbeli, síkbeli viszonyok tanításához, gyakorlásához, illetve a 
programozási alapismeretek játékos, cselekvésbe ágyazott elsajátításához. A BeeBot memóriája 40 lépésig, a Blue-Boté pedig 200 lépésig programozható. A BlueBot okoseszközről vagy PC-ről is vezérelhető. A Blue-Bot a Bee-Bottal ellentétben okoseszközről vezérelve 45 fok-ban is el tud fordulni. Az eszközökön elkészített kódot közvetlen Bluetooth-kapcsolaton keresztül lehet elküldeni a robotméhecskének. Természetesen, csak Bee-Bot üzemmódban is használható" (Aknai, 2020, 157.).

Az Ozobotok „Kézben, tenyérbe elférő zsebrobotok. Kétféle változat van belőlük, az Ozobot Evo és Ozobot Bit. A kódolás tanítására-tanulására és a kreativitás kibontakoztatására fejlesztették ki. Kétféle módon kódolhatók: online az OzoBlockly-val és „képernyő-mentesen”, színes kódokkal. A színes kódok mondják meg az Ozobotoknak, hogy mit kell tenniük. A színes kódok olyan alapvető kódolási elveket tanítanak, mint az ok-okozat, a kritikus gondolkodás és a hibakeresés. A robotok érzékelőkkel követik a vonalakat és elolvassák a jelölőkkel (vagy matricákkal) készített színkódokat. A „színes” programozáshoz színkódtábla van a segítségünkre" (Aknai, 2020, 158.).

Az Edison robotok a játékos tanulás motiváló eszközei. Ennek a robotnak előnye, hogy több nyelven is programozható, kisebbeknek a beépített vonalkódtól a block- és ikonos programozáson keresztül a komolyabb háttértudással rendelkező felhasználók számára is „érthető” ED-
Phyton-ig. Fejleszti a problémaalapú feladatmegoldást, az algoritmikus gondolkodást.

Az mBot egy STEM kódoló robot kezdőknek, amely egyszerűvé és szórakoztatóvá teszi a robotprogramozás tanítását és tanulását. Egy csavarhúzóval és a lépésről lépésre szóló utasításokkal a gyerekek a semmiből építhetnek robotot, és megtapasztalhatják a gyakorlati alkotás örömeit. Menet közben megismerkednek különféle robotgépekkel és elektronikus alkatrészekkel, megismerkednek a blokkalapú programozás alapjaival, és fejlesztik logikus gondolkodásukat és tervezési készségeiket.

A padlórobotokon kívül a LEGO Education WeDO, LEGO Boost és a Mindstorms EV3 robotok azok, amelyek feltűnnek a hazai iskolai palettában (többnyire a tehetséggondozás egyik formájaként). Kiss $(2014,89$. o.) szerint „,a LEGO cég MINDSTORMS robotjai alkalmasak a tanórai használatra, az algoritmikus gondolkodás fejlesztésére. A bennük rejlő kreatív lehetőségek a természettudományos oktatás új alapokra helyezését is elősegíthetik. A motivációs szerepük viszont meghaladja a »hagyományos« programozás-oktatásban eddig használt eszközökét."

Emellett az oktatási célú robotika terjedésével egyidejűleg gyermekeknek szánt hazai és nemzetközi robot versenyek is elkezdtek felbukkanni a LEGO Mindstorms, Tetrixx, Elekit vagy a RoboKing robotok használatával. 


\section{A robotokkal történő oktatás}

\section{hatásainak kérdőíves vizsgálata}

A vizsgálat célja, hogy pedagógusoktól származó véleménygyűjtés (kérdőív) segítségével betekintés kapjunk a hazai oktatási célú robotika helyzetébe. Emellett kíváncsiak voltunk arra is, hogy a pedagógusok milyen véleménnyel vannak az oktatási célú robotika, mint élménypedagógiai módszer fejlesztő hatásaival kapcsolatban: észlelik-e pozitív hatását a tanulók fejlődésében, és ha igen tapasztalataik szerint, mely területeken mutatkozik ez meg leginkább?

\section{Hipotézisek}

A vizsgálatunkban három kérdésre kerestük a választ:

1. Miként alakult a robotok bevonásával történő oktatás időbeli elterjedése az elmúlt években (különös tekintettel 2016, a Digitális Jólét Program indulása óta)?
2. Milyen arányban jellemző a robotok oktatási célra történő használa tatanórán belüli, illetve kívüli keretek között?

3. Milyen típusú robotok alkalmazása jellemző a megkérdezettek körében?

\section{Minta}

A vizsgálatban $n=84$ fő pedagógus vett részt. A pedagógusok az ország 12 megyéjéből válaszoltak a kérdőív kérdéseire (1. ábra). A válaszadók többsége kisebb településen (falvakban vagy kisvárosban) végez pedagógiai tevékenységet. A minta nem reprezentatív.

A demográfiai eloszlás szempontjából érdemes tájékozódni a különböző településeken dolgozó pedagógusok életkori megoszlásáról (2. ábra), hiszen a digitális kultúra (melynek jelen esetben része a robotikai eszközök alkalmazásának képessége) tekintetében gyakran említik a generációs különbségeket (Prensky, 2001).

1. ábra. A válaszadók munkahelyének eloszlása megyei szinten és a település típusának viszonylatában (n=84). Forrás: Szerző́k

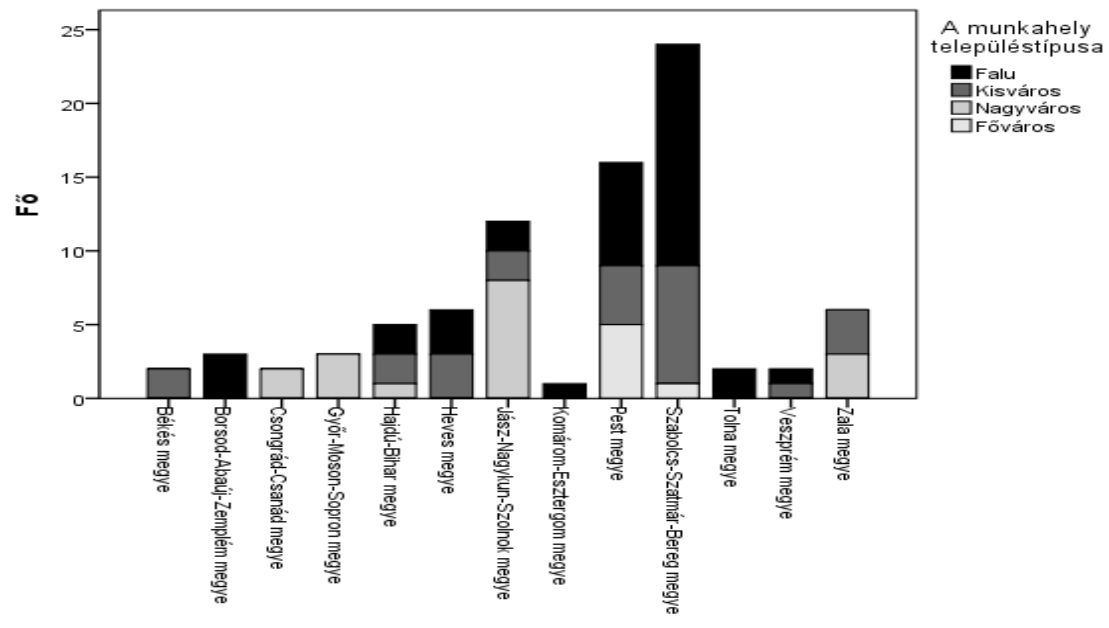


2. ábra. A válaszadók életkori megoszlása a különbözö települestipusokon (n=84). Forrás: Sžrzö́k

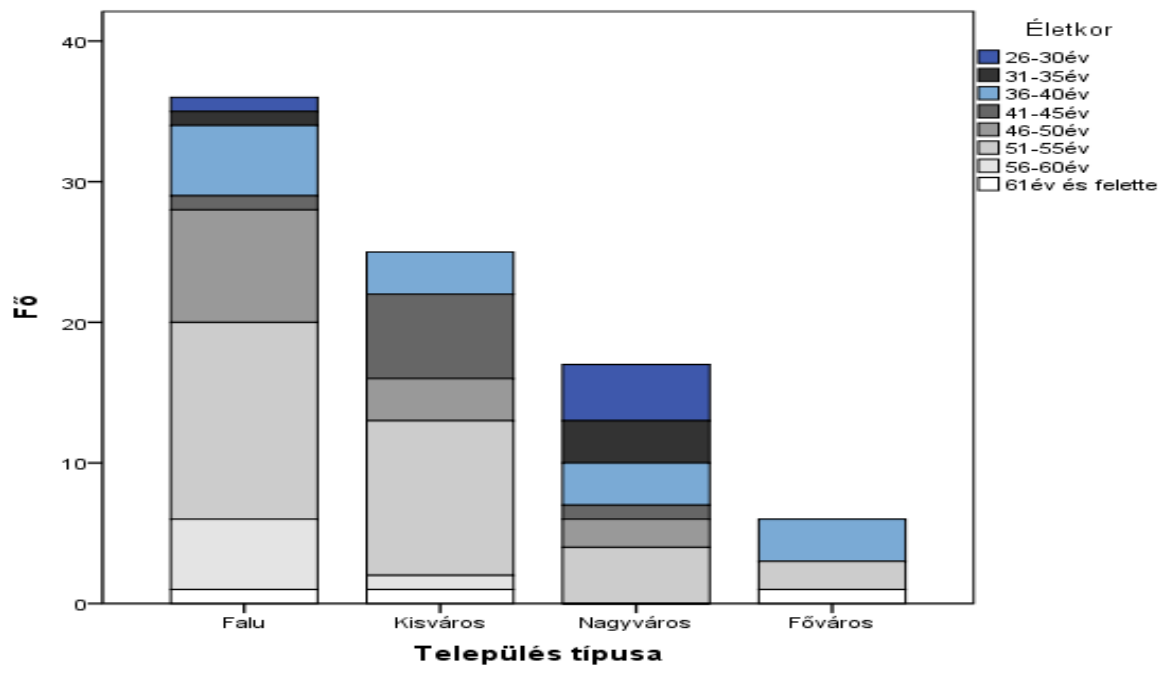

A válaszadó pedagógusok jelentős része a 46 év és afeletti korosztályból tevődik ki, azaz ők az X generációként, illetve a Babyboomerek-ként emlegetett generáció tagjai. Életkori adataink megegyeznek a közoktatás indikátorrendszere 2019-ben közölt adatokkal (Varga, 2019), ahol arról számolnak be, hogy 2008 és 2018 között átlagosan egyre idősebb pedagógusokat foglalkoztatott a hazai köznevelési rendszer. Nagymértékben csökkent a 30 évesnél fiatalabb és a 30-39 éves korcsoport aránya. Az 50-59 éves pedagógusok aránya ugyanakkor jelentősen nôtt (27-rôl 35 százalékra), és nőtt a 60 évesnél idősebb tanárok aránya is. A mintánk is megerősíti ezt az állapotot, hiszen a válaszadók legjelentősebb egységét az 51-55 évesek teszik ki. A minta alapján arra lehet következtetni, hogy (amennyiben mitavételünk reálisan képezi le az életkori viszonyokat, akkor) jelentős életkori és generációs különbség van a pedagógusok és az általuk tanított tanulók között, mely nehézséget jelenthet az oktatási célú robotikában való tájékozódás/tájékozottság terén.

Bár a Digitális Jólét programban (2016, 72. o.) megfogalmazásra kerül, hogy „legalább egy számítástechnika szaktanteremben $[\ldots] 3$ tanulónként egy programozható robotot kell biztosítani", azonban ezen technológiák oktatási célú felhasználásáról a különböző településeken jelenleg nincsenek ismereteink.

\section{Módszer}

A vizsgálat elvégzéséhez saját összeállítású kérdőívet alkalmaztunk. Az eredményeket SPSS program használata segítsé- 
gével elemeztük, leíró statisztikai elemzés és Khi-négyzet $\left(\chi^{2}\right)$ teszt alkalmazásával.

\section{Eredmények}

A vizsgálat kiinduló pontjaként rákérdeztünk arra, hogy a válaszadók intézményeiben rendelkezésre állnak-e az oktatási célú robotikai eszközök, és, ha igen, akkor mióta van lehetőség a robotokkal történő oktatás megvalósítására. Valamennyi válaszadó arról számolt be, hogy az intézményükben van elérhető eszköz, azonban a robotokkal történő oktatás elindulása már eltérô időintervallumokra datálható (3. ábra). A 3. ábra kategória tengelyén látható négy időszakhoz tartozó értékek egyenletes eloszlást feltételező várható és megfigyelt gyakorisága szignifikánsan különbözik egymástól $\left(\chi^{2}=15,524, d f=3, p \leq\right.$
0,001). A helyzetkép a Digitális Jólét Program elindításának megfelelően rajzolódik ki. A program 2016-os bevezetése előtti időkben, még csak kevés intézményben (a válaszadók esetében mindössze 8-ban, kevesebb, mint a választadó intézmények 10\%-ában) foglalkoztak oktatás robotikai eszközökkel (főként pályázati forrásokból előteremtve azok költségeit), ugyanakkor a program öt évvel ezelőtti (2016. évbeli) bevezetésével szinte egyidőben az iskolák további kb. 20\%-ában $(n=24)$ már lehetővé vált az oktatási célú robotika eszközök használata. Jó hír, hogy a növekvő tendencia folytatódik, ám megjegyzendő, hogy az intézmények 27,72\% -ában $(n=33)$ csak 2-3 éve van robotokkal történő oktatás, sőt olyan intézmények is vannak ahol csak 1 éve, vagy annál kevesebb ideje van jelen a robotokkal történő oktatás.

3. ábra. A robotokekal történö oktatás megjelenésének idöbelisége a különbözó intézményekben (n=84). Forrás: Sžerzộk

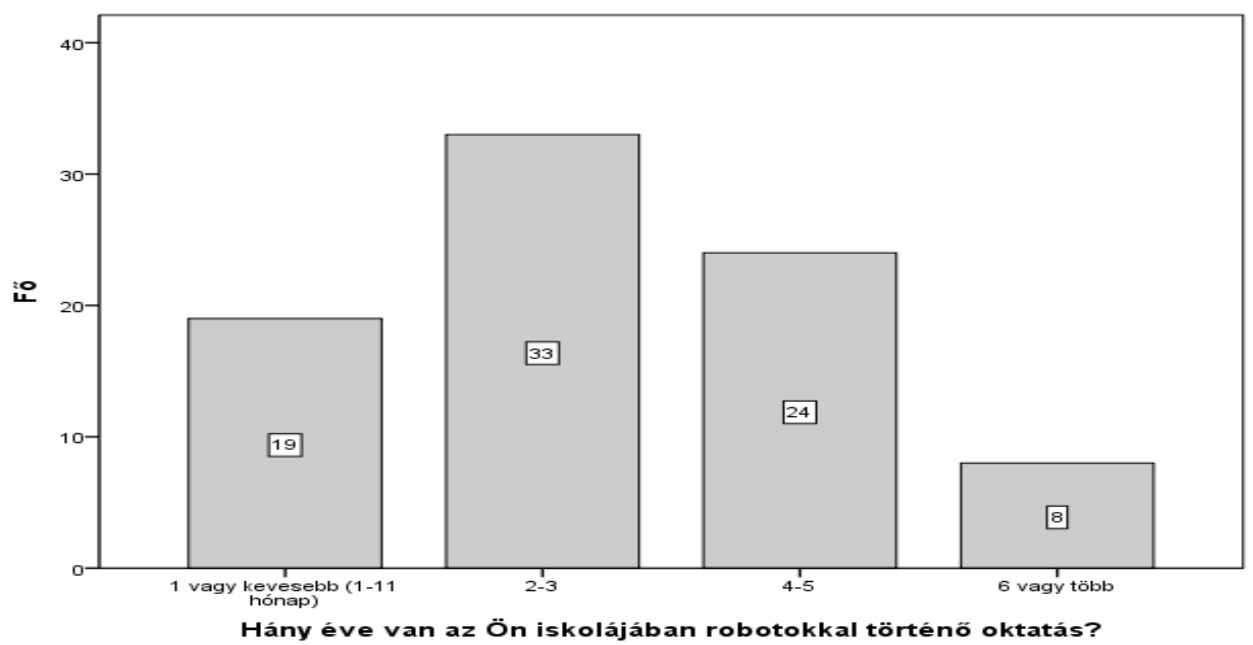


Kíváncsiak voltunk arra is, hogy a pedagógusok milyen tanórán belüli, kívüli keretek között tudják elképzelni a robotok használatát a tanításuk során.

Az oktatási robotok tanórai kereteken belül történő használata esetében $\left(\chi^{2}=\right.$ $10,714, d f=1, p \leq 0,001)$ és a tanórán kívüli használat tekintetében is $\left(\chi^{2}=10,714, d f=\right.$ $1, p \leq 0,001)$ szignifikánsan kevesebb a használatra utaló ,igen, használunk oktatási robotokat ilyen keretek között" jellegû válasz (mindkét esetben a válaszok kb. 30\%-a), mint a ,nem, nem használunk oktatási robotokat ilyen keretek között” értelmű válasz (v.ö.: 4. ábra). A tanórán belüli és kívüli keretek között nincs lényeges különbség abból a szempontból, hogy válaszadóink intézményeiben használnak-e oktatási robotokat az adott keretek között. Ugyanakkor a válaszokból az is kiderült, hogy a pedagógusok nagy többsége csak a tehetséggondozás céljából $(n=55)$, esetleg jutalmazás céljából $(n=10)$ használja a robotikai eszközöket, emellett 10 fô a felzárkóztatási célú felhasználást említette és csak 1 fó tartotta élménypedagógiai lehetőségnek. Mindebből arra lehet következtetni, hogy a robotikai eszközök használata még nem épült be teljesen sem a hétköznapi pedagógiai tevékenységek közé (és félő, hogy nem is jut el minden tanulóhoz), sem az élménypedagógiai repertoárba. Ez utóbbinak feltehetően az lehet az oka, hogy a hagyományosan élménypedagógiával foglalkozó pedagógusok talán kevésbé ismerik a robotikai lehetőségeket, és fordítva: a robotika művelői talán kevésbé bevonódottak az élménypedagiába, így e két terület képviselőinek fogalom- és módszertani eszköztára még nem hatott egymásra kellő képpen.

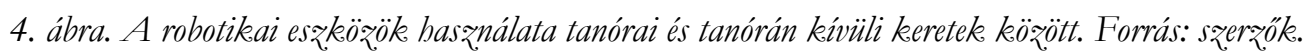

Használnak tanóra keretein belül robotokat?

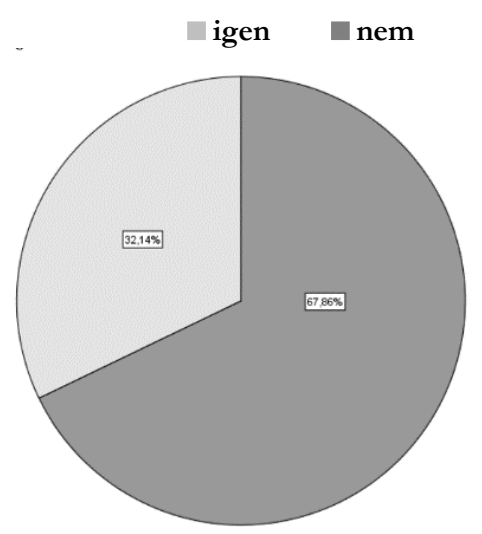

Használnak tanóra keretein kívül (pl. szakköri foglalkozás alkalmával) robotokat? igen $\quad$ nem

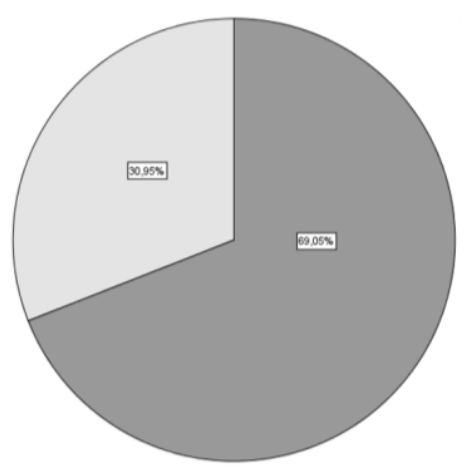


Az intézményekben oktatásrobotikai céllal használt robotok típusai változatosak: az intézményekben 27 féle különböző eszköz használatáról számoltak be. A legnépszerűbb eszközök a Bee-Bot, BlueBot méhecske, valamint a LEGO-WeDo, LEGO-Mindstorms (5. ábra). A robotikai eszközök mennyisége tekintetében jelentôs különbségek vannak az intézmények között. Van olyan intézmény, ahol csak egy eszköz áll rendelkezésre, míg a legtöbb eszközzel rendelkező intézményben 138 darab eszköz is a tanulók rendelkezésére áll.

Azokban az intézményekben, ahol nagyobb mennyiségű (több mint 25 darab) eszköz áll rendelkezésre, ott az állami támogatás mellett alapítványi, pályázati vagy önköltséges formában szerezték be a robotokat. Két esetben felmerült az is, hogy az intézményben nincs robotikai eszköz, hanem a pedagógus a saját eszközeit használja az oktatás során. A pedagógusok 2 fó kivételével azt nyilatkozták, hogy a robotokkal történő oktatásnak pozitív hatásai vannak a tanulók fejlődésére.

\section{Megvitatás}

A 2016-ban bevezetésre került Digitális Jólét Program hazánkban is megnyitotta az utat az oktatási célú robotikai eszközök intézményes beszerzése irányába, így (elvileg) a lehetőség adott a tanulók ezáltal történő fejlesztéséhez. Függetlenül attól, hogy a pedagógusok kisebb vagy nagyobb településen dolgoznak-e, többnyire már rendelkezésre állnak a szükséges eszközök.

5. ábra. Az intézményekben oktatásrobotikai céllal használt robotok típusai (n=84). Forrás: szeroő

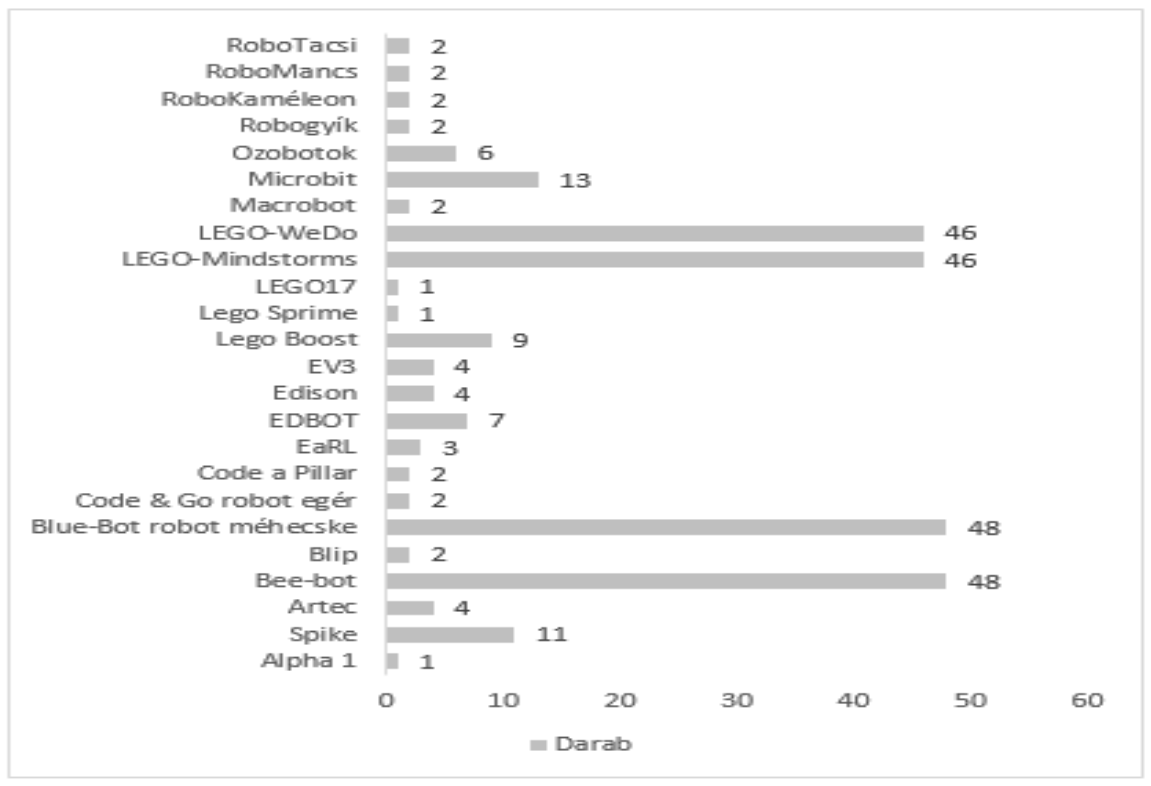


A vizsgálati tapasztalataink azt mutatták, hogy a válaszadók munkahelyein ugyanakkor a mennyiségi ellátottság terén jelentős különbségek vannak. Megjegyzendő az is, hogy bár látványosan növekedett az utóbbi években a robotikai eszközök száma a köznevelési intézményekben, kérdés, hogy az iskolák képesek lesznek-e tartani informatika már-már közhelyszerűen gyors fejlődésével az ütemet. Lehetőségük lesz-e beszerezni a mindenkori korszerű oktatásrobotikai termékeket? A technikai eszközpark folyamatos megújulása, megújítása elengedhetetlen a robotikai fejlődéssel való lépéstartás érdekében.

Elgondolkodtató továbbá, hogy a pedagógusok a robotikai technológiákat nem az óratartás természetes eszközeként kezelik, hanem a tehetséggondozás vagy időnként a jutalmazás eszközeként használják. Ergo: úgy tűnik, hogy az oktatásrobotika napjainkban még inább kuriózum, semmint hétköznapi oktatási eszköz. Azt viszont minden pedagógus megfogalmazta, hogy a robotokkal történő tanulás kedvező, motiváló élmény a tanulók számára.

A pedagógusok véleménye az oktatási célú robotikai eszközök fejlesztő hatásait illetően nagyon kedvező. A pedagógusi vélemények alátámasztása érdekében azonban érdemes lenne empirikus bizonyítékokkal alátámasztani a robotokkal történő oktatás fejlesztő hatását.

\section{Kitekintés, zárógondolatok}

A robotokkal történő oktatás viszonylag újszerű jelenség a hazai iskolákban, ebből következően nagy előnye az újdonság- értéke a tanulók számára. Ha azt az ideális esetet feltételezzük is, hogy a pedagógusok nyitottak az oktatásrobotikai eszközök használata felé, akkor is felmerül, hogy ezek az eszközök már nem a hagyományos pedagógiai felkészültséget igénylik, ezért a technológiák használatához szükséges megfelelő kompetenciák kialakítása új kihívást jelenthet a neveléssel foglalkozók és a pedagógusképző intézmények számára egyaránt.

Egyre többször jelenik meg, hogy a 21. század a „homo digitalis” kora (Szlafkai, 2009, Montag, 2018). Az emberiség olyan kulturális és társadalmi változáson esik át, melynek következtében a Gutenberggalaxisból áttér(t)ünk egy újtípusú Internet-galaxisba, ahol az internet, az IKT eszközök és oktatási technológiák használatának képessége, tudása a pedagógiai metódusok alapja. Ebben a világban egyesek (például Kurup, 2019, Jacobs, 2019) már olyan sci-fi-be illő elképzeléseket vizionálnak, mint a „Homo Roboticus", a mesterséges intelligencia és a robotrendszerek összeolvadásával létrejövô szuper ember-gép hibridek megjelenése. Mindez azt gondolnánk, hogy a távoli jövő gondolata, viszont a robotok - illetve vezérlésüket ellátó mesterséges intelligenciák alapja - már ott vannak a munkahelyeken, az egészségügyi intézményekben, a háztartások smart eszközeiben és ott vannak a köznevelési intézményekben is.

A pedagógusok feladata a tanulók felkészítése a jövőben való boldogulásra, de be kell látni, hogy a robotokkal történő oktatás már nem a jövő, hanem a közvetlen 
jelen alapfeladata. Kérdés tehát: felkészült a „robotok korára” a hazai pedagógus képzés, illetve pedagógus társadalom? Alkalmasak vagyunk/leszünk köznevelési, szakképzési és felsőokttaási intézményeinkben olyan felnőttekké, szakemberekké nevelni a ránk bízott gyermekeket, fiatalokat, akik értő, felelős, etikus, ráadsul praktikus módon tudnak élni a robotok nyújtotta lehetőségekkel? Amennyiben nem vagy csak bizonytalan módon tudunk ,igen”-t válaszolni e kérdésekre, akkor itt az ideje, hogy változtassunk!

\section{Irodalom}

A Kormány által 1536/2016. (X. 13.) Korm. határozattal elfogadott Magyarország

Digitális Oktatási Stratégiája

Aknai Dóra Orsolya (2020): A robotika szerepe az SNI tanulók fejlesztésében: Gyermeknevelés. 8. 2. sz. 146-163.

Digitális jólét program (2019).

Digitáliskompetencia-keretrendszer,

Budapest. Letöltés: 2021.06.10. Web:

https://digitalisjoletprogram.hu/hu/ta rtalom/digkomp

Jacobs An, Maus Michel, Meeusen

Romain, Tytgat Lynn (2019). HOMO

ROBOTICUS: 30 Questions and Answers

on Man, Technology, Science \& Art.

VUBPRESS, Brussels.

Kärnä-Lin, Eija; Pihlainen-Bednarik, Kaisa; Sutinen, Erkki; Virnes, Marjo (2006). Can Robots Teach? Preliminary Results on Educational Robotics in Special Education. Conference: Proceedings of the 6th IEEE International
Conference on Advanced Learning Technologies, ICALT 2006, 5-7 July 2006, Kerkrade, The Netherlands. DOI: $10.1109 /$ ICALT.2006.1652433

Kispéter Andrea, Sövényházi Edit (2008): Élménypedagógia - Csapatépitó játékok.

Bába Kiadó, Szeged.

Kiss Róbert (2015). Robotika a

közoktatásban. Kecskeméti Bányai Júlia Gimnázium, Kecskemét.

Kraetzschmar, Gerhard, K. (2009). Educational Robotics: On the Role of

Robotics in Learning and Education.

Bonn-Rhein-Sieg University of Applied Sciences, Department of Computer Science, German.

Kurup Ravikumar (2019). Homo galacticus, Homo roboticus and Human Extinction. Lap-Lambert, Academic Publishing. Mező Ferenc (2021). Felfedeztetéses tanulást segítő gyakorlatok az OxIPOmodell alapján. OXIPO:

Interdiszciplináris e-folyóirat 3:3. pp. 83-

97. doi: 10.35405/OXIPO.2021.3.83

Mező Katalin (2015): Kreativitás és élménypedagógia. Kocka Kör, Debrecen.

Molnár, Balázs (2019). Paradigmaváltások az elektronikus tanulási környezetek fejlődésében I. Mesterséges Intelligencia 1 : 1 pp. 41-52. DOI: 10.35406/MI.2019.1.41

NAR (2020). A Nemzeti Alapkészségfejlesztési Rendszer Nyitott Tanulási Központok Hálózata. Gradus Vol 1, No 1 (2014) 81-93

Net1: Robot teachers of Tampere. Letöltés: 2021.10.26. Web: 
https://www.tampere.fi/en/city-oftampere/info/currentissues/2018/03/19032018_1.html

Net2. McNamara, Scott; Cyr, Martha; Rogers, Chris; Bratzel, Barbara (1999). LEGO Brick Sculptures and Robotics in Education. Letöltés ideje: 2020. 10. 25. Web:

https://er.jsc.nasa.gov/seh////Robot PDF_Files/lego brick robots.pdf
OECD (2001). Knowledge and skills for life: First results from PISA 2000. Paris: OECD Publications

Prensky, M. (2001). Digital Natives, Digital Immigrants, Part 1. On The Horizon, 9, 3-6. DOI:

$\underline{10.1108 / 10748120110424816}$

Szlafkai Éva (2009). A homo digitalis kora. MÜTF, Budapest.

Varga Júlia (Szerk.)(2019). A közoktatás indikátorrendszere 2019. KRTK KTI, Budapest. 